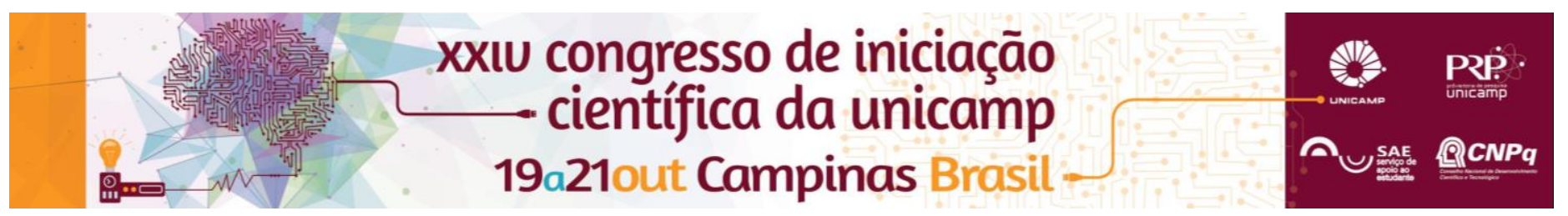

\title{
The Indigenous Theme in History Teaching: a study of the state of the art (2000-2016)
}

\author{
Jonathan C. Ávila*
}

\begin{abstract}
This work presents a literature review of scientific articles produced in the field of history and education focused on studies that address how the indigenous history is taught in History classes on educational institutions. The indexer 'Biblioteca Digital Vérsila' was utilized as the serch engine. The analysis covered 14 articles published between 2000 and 2016, where the majority of studies had the tendency to analyse the indigenous history as a mechanism to form intercultural identities.
\end{abstract}

\section{Key words:}

History Teaching, Indigenous History, State of the Art.

\section{Introduction}

According to Bittencourt (2003), the absence and (or) bad interpretation of the indigenous population in History teaching is the result of a political and ideological point of view that suggests these people do not have a history. However, during the last three decades important changes have occurred that collaborated for the appreciation of the indigenous narratives when teaching History. The 1988 Federal Constitution recognized the indigenous populations as Brazilian citizens and established their rights. Later, the 1996 Law of Guidelines and Bases complemented by the 2008 Law $n^{\circ} 11.645$ mandated the inclusion of the Afro-Brazilian and Indigenous history and culture into all educational curriculums. Based on the awareness about these laws and rights related to indigenous history and culture, this study proposes an analysis on the 'State of the Art' of articles that address the indigenous theme in History teaching during the first two decades of the 21 st century.

\section{Results and Discussion}

Based on the quantitative and qualitative methodology of the 'State of the Art' analysis, articles of several Brazilian universities published on scientific journals or academic conferences proceedings were included if the indigenous theme in History teaching was addressed.

The literature search was conducted in national databases using an indexer of academic archives with open access called 'Biblioteca Digital Vérsila', due its search engine precision, which considers more than 20 factors as it searches for a key word.

After the literature search, the selected key words were organized in descending order, from those that returned fewer results to those with more results. All articles were reviewed and selected based on title and abstract. Only unprecedented works were considered for analysis based on the results of each key-word. From the 292 search results, only 14 articles were selected, not because there were not enough articles on this topic but because the majority of the results reported theses and dissertations, which were considered as repeated work.

Results from the qualitative approach showed, in essence, the concern of researchers to appreciate the indigenous narratives in order to insert the indigenous culture in the identity of the Brazilian citizens. The results from the quantitative approach, among other data, presented the institutions that conducted research about the topic, their geographical region, and their respective number of published articles, as shown below.

Table 1. Institutions that conducted researches about the topic.

\begin{tabular}{|l|l|c|}
\hline State & Institutions & $\begin{array}{l}\text { Number } \\
\text { Articles }\end{array}$ \\
\hline São Paulo & $\begin{array}{l}\text { Unicamp, USP, } \\
\text { UFSCAR e } \\
\text { UNIFESP }\end{array}$ \\
\hline Rio de Janeiro & UERJ & 3 \\
\hline Paraíba & EPB e UFPB & 2 \\
\hline Pará & UFOPA & 1 \\
\hline Rondônia & UNIR & 1 \\
\hline Bahia & UNEB & 1 \\
\hline $\begin{array}{l}\text { Mato Grosso do } \\
\text { Sul }\end{array}$ & UFMS & 1 \\
\hline Minas Gerais & UFMG & 14 \\
\hline \multicolumn{1}{|c|}{ Total: } & \multicolumn{1}{|c|}{12} & 1 \\
\hline
\end{tabular}

*written in partnership with UFOPA.

Source: The author.

\section{Conclusions}

It was evident that there is an increase in the concern to produce research about the inclusion of indigenous issues in History teaching after the end of the first decade of the 21st century. However, due to the difficulties presented by the articles analyzed, it is essential that such works are widely disseminated and discussed in educational institutions.

\section{Acknowledgements}

I thank the research department at UNASP-EC and the research coordinator of the project: History, Narratives and Education, Prof. ${ }^{\text {a }}$ M. ${ }^{\text {a }}$ Dayana de Oliveira Formiga for the opportunity to participate as a PIBIC student.

${ }^{1}$ BITTENCOURT, C. M. F.. Identidade nacional e ensino de História do Brasil. In: KARNAL, L.. (Org.). História na sala de aula. 1ed.São Paulo: Contexto, 2003, v., p. 185-204. 